\title{
Effects of strain, live weight and micro-environment on body weight development of cane rat (Thryonomys swinderianus) in the humid tropics
}

"Jesuyon, O. M. A. and T. O. Bankole

Department of Animal Science, University of Ibadan, Ibadan, Nigeria

*Animal Breeding and Genetics Unit, Department of Animal Production and Health

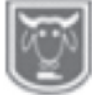

Federal University PMB 373, Oye-Ekiti, Nigeria

*Corresponding Author: dr.oluwatosinjesuyon14@gmail.com

\begin{abstract}
Interactive effects of strain, live weight and a non-genetic factor namely micro-environment on the live weight development of cane rats reared in captivity were investigated over a seven-month period. A total of seventy-nine (79) cane rats (Thryonomys swinderianus) originating from three different sources (strains) and of four body weight categories were used for the study. The treatment design was $4 \times 3$ Factorial of Live-weightXStrain randomly assigned to 3 Houses (block) using RCBD, while statistical analysis utilized GLM procedure of $S A S^{\circledR}$ (1999). Data were recorded monthly based on Treatment-combinations and Housemicro-environment. Results revealed that effects of strain, live weight category and housemicro-environment on strains were significant. Consequently, interactive effect of strainXhouse-micro-environment was found most depressing on Lawole $>$ FRIN $>$ Bamidele, while strainXlive-weight category interaction exerted most positive influence on Lawole strain which demonstrated the highest ability for body weight development than other two strains. Findings revealed that interactive effect of STRxHME was most significant on weight development. Bamidele strain was identified as most acclimatized and adaptable of the three strains based on least body weight sensitivity and variation between HMEs. Different strains of cane rat in captive rearing systems would exhibit different and specific reaction norms under interaction of strain, Body weight and House-micro-environment. This knowledge is useful for feeding regimes, husbandry and breeding schemes for cane rats in humid tropics.
\end{abstract}

Keywords: Grasscutter, adaptability, South-West Nigeria, Housing-microenvironment

\section{Introduction}

The study was designed to investigate effects of strain (STR), Initial live-weight (LWG) category, house-micro-environment (HME) and their interactions on body weight development of cane rat in captive rearing system - cages placed in open-sided pens. Grasscutter or greater cane-rat (Thryonomys swinderianus) is a hystricomorphic rodent endemic to African savannah grasslands, forest clearings, cultivated lands and secondary forests of Africa (Asibey and Addo, 2000; Opara, 2012). It is a monogastric herbivore, a good food converter of forage and high fibre roughage to protein; and often practices caprophagy (Hemmer, 1990). It is a highlyprized bush meat, source of protein, and a delicacy, but an agricultural pest of cereals and other crops on farms (Asibey, and Addo, 2000; Yeboah, and Adamu, 1995). It contributes to both local and export earnings of many West African countries and therefore hunted aggressively (GEPC, 1995) from the wild. These factors necessitate its commercial production in captivity to bridge the protein gap of many people in the sub-region. Body weight 
Effects of strain, live weight and micro-environment on body weight development of cane rat

development in meat animals often accompanies growth as cells and tissues become differentiated and increase in complexity. Development in animal involves the directive coordination of all diverse physiological processes of growth, cellular differentiation and changes in body shape and form, until maturity is reached, and this could be captured by monitoring, weighing and plotting the growth curve or modelling the body weight (Peters, et al. 2005). Genetic factors such as genotype, breed, strain, line, variety, maturation rate, sex, live weight, size, parity, growth rate, muscling etc. affecting growth would also influence weight development. Thus Animals with high inherent growth potential could produce more efficiently on optimum feeding regime and plane of nutrition (Meat Science, 2015). Measurable environmental effects influencing animal performance and development, called nongenetic factors, include chronological age, nutrition, feeding level, management, season, year, diurnal variation, etc (Annor et al., 2012). At higher plane of nutrition, more rapid optimum body composition is usually achieved. Studies have been conducted on growth (Annor et al., 2008, 2012; Okorafor et al., 2013) and other aspects of cane rat production such as digestive physiology (Yapi et al., 2012), semen characteristics and spermiology (Olukole, and Obayemi 2010; Olukole, et al. 2014), performance and energy requirement (Wogar and Agwunobi, 2012), control and zoonotic role (Smith et al., 2002; Opara, 2012), reproduction (Ngoula et al., 2012), body characteristics (Jori and Chadonnet, 2001), biology and ecology (Ntiamoa-Baidu, 1980 ) and husbandry (Owen and Dike, 2012). However, few studies have investigated the effect of such interactions among strain, live weight and microenvironment on the body weight development of cane rat. The research was therefore initiated to provide answers to two questions namely:

1. What important interacting factors are acting on body weight development of cane rats in captivity in hot humid environment?

2. What are the effects of these interactions on body weight development of cane rat?

The relevant hypothesis was that the effects of interacting factors of StrXLWG, StrXHME and StrXLWGXHME on body weight development of cane rat were not significantly.

\section{Materials and Methods Experimental site}

The research was carried out at the Grasscutter Unit, University of Ibadan, Nigeria, located on Long. $7.4417^{\circ} \mathrm{N}$ and Lat. $3.8835^{\circ} \mathrm{E}$, Alt. $195.55 \mathrm{~m} \mathrm{MSL}$, mean temperatures of $35.45^{\circ} \mathrm{C}$ and $27.50^{\circ} \mathrm{C}$ for January and August.

\section{Experimental animals and management}

Three strains of Thryonomys swinderianus totaling seventy-nine individuals were used for the study. The foundation animals originating from FRIN, Bamidele and Lawole Farms respectively, along with their offspring that were being reared onfarm in ratio 41:25:13 were of varying body weights. At onset of experiment, all cane rats were weighed with a $5-\mathrm{kg}$ capacity Camry scale and tagged for identification, and grouped within strain into four initial weight categories of $\leq 2.0,2.1-3.0,3.1-4.0$ and $4.1-5.0 \mathrm{~kg}$ (Table 1). Two factors, Body weight category (4) and Strain (3) were combined into 12 Treatment-combinations (Table 2). Subsequently individuals in each treatment-combination were assigned randomly to houses $\mathrm{A}, \mathrm{B}$ and $\mathrm{C}$ respectively. All animals and houses were subjected to same management and 


\section{Jesuyon and Bankole}

nutrition. Forage, which was either Elephant grass (Pennisetum purpureum) or Maize (Zea maize) stalk, was offered twice daily and was supplemented with a commercial concentrate grower mash ration of $70 \mathrm{~g} / \mathrm{animal} / \mathrm{day}$, containing $15 \%$ $\mathrm{CP}$ and $1946.9 \mathrm{kcal} / \mathrm{kg} \mathrm{ME}$ while water was offered ad libitum.

Table 1: Distribution of experimental materials by strain and body weight category

\begin{tabular}{llllll}
\hline Body weight & $\leq 20 \mathbf{k g}$ & $\mathbf{2 . 1 - 3 . 0 k g}$ & $\mathbf{3 . 1 - 4 . 0 k g}$ & $\mathbf{4 . 1 - 5 . 0 k g}$ & \\
Category & WC1 & WC2 & WC3 & WC4 & Total \\
\hline FRIN & 3 & 14 & 13 & 4 & 34 \\
Bamidele & 5 & 13 & 6 & 4 & 28 \\
Lawole & 3 & 8 & 3 & 3 & 17 \\
Total & 11 & 35 & 22 & 11 & 79 \\
\hline
\end{tabular}

WC $=$ Weight category

Table 2: Experimental Treatment-Combinations

\begin{tabular}{llll}
\hline Treatment No. & $\boldsymbol{\beta}$ category & T category & No. of Individuals \\
\hline 1 & 1 & 1 & 3 \\
2 & 1 & 2 & 5 \\
3 & 1 & 3 & 3 \\
4 & 2 & 1 & 14 \\
5 & 2 & 2 & 13 \\
6 & 2 & 3 & 8 \\
7 & 3 & 1 & 13 \\
8 & 3 & 2 & 6 \\
9 & 3 & 3 & 3 \\
10 & 4 & 1 & 4 \\
11 & 4 & 2 & 4 \\
12 & 4 & 3 & 3 \\
\hline
\end{tabular}

$\beta=$ Body weight, $T=$ Strain

\section{Experimental design}

The Treatment design was $4 \times 3 \times 3$ factorial arrangement of Body weight category, strain and house-micro-environment in randomized complete block design (CRD), using house as blocking factor.

\section{Data collection and Analysis}

Live weight measurements were observed and recorded for a period of seven months (February - August). Month was used as replicate during analysis of data. Data were subjected to General linear model (glm) procedure which included Least square means (LSM), ANOVA, Tukey's t-test $(p<0.05)$ of $\mathrm{SAS}^{\circledR}$ for Windows $(1999)$. Interactions were compared using Standard error of Mean (SEM) computed using the relation $\sqrt{ }(\mathrm{RMSE} / \mathrm{N})$, where RMSE was the root mean square error obtained from ANOVA output, and $\mathrm{N}$ was the number of observations. The research was initiated to study the nature of interaction among Strain (STR), Live weight (LWG) and Housemicro-environment (HME) on body weight development of grasscutters. Final statistical model $\left(p<0.0001, r^{2}=0.82\right)$ adopted for study based on comparison of plots of normal probability of effects, 


\section{Effects of strain, live weight and micro-environment on body weight development of cane rat}

contour plot, surface plot and regression model was:

$\mathrm{y}_{\mathrm{ijk} \mathrm{l}}=\mu+\mathrm{T}_{\mathrm{i}}+\beta_{\mathrm{j}}+\delta_{\mathrm{k}}+\mathrm{T} \beta_{\mathrm{ij}}+\mathrm{T} \delta_{\mathrm{ik}}+\beta \delta_{\mathrm{jk}}+$ $\mathrm{T} \beta \delta_{\mathrm{ijk}}+?_{\mathrm{ijkl}}$

where,

$\mathrm{y}_{\mathrm{ijkl}}=$ Live weight response of individual cane rat in ith strain, jth weight group, kth house and lthreplicate $(\mathrm{kg})$

$\mu=$ Overall mean of the population, fixed and unknown

$\mathrm{T}_{\mathrm{i}}=$ Effect of strain, level $\mathrm{i}$, on live weight ( $\mathrm{i}=1$ to 3 )

$\beta_{\mathrm{j}}=$ Effect of weight category, level k, on live weight ( $\mathrm{j}=1$ to 4 )

$\delta_{\mathrm{k}} \quad=$ Effect of house-micro-environment, level $\mathrm{k}$, on live weight ( $\mathrm{k}=1$ to 3$)$

$\mathrm{T} \beta_{\mathrm{ij}}=$ Interactive effect of strain and live weight category.

$\mathrm{T} \delta_{\mathrm{ik}}=$ Interactive effect of strain and house-micro-environment $\beta \delta_{\mathrm{jk}}=$ Interactive effect of weight category and house-micro-environment $\mathrm{T} \beta \delta_{\mathrm{ijk}}=$ Interaction effect of strain, weight category and house-micro-environment $?_{\mathrm{ijkl}}=$ Residual error effect composed of all factors not observed in strain i, weight group $\mathrm{j}$, house-micro-environment $\mathrm{k}$ and replicate 1 .

All applicable international, national, and/or institutional standard ethical norms and guidelines for the care and use of animals were followed.

\section{Results}

Effects of strain, body-weight group and house-microenvironment on body-weight development of cane rats

The effect of STR, LWG and HME on body weight development of studied cane rats is shown in Table 1. ANOVA results revealed significant differences among LWG categories $(p<0.0001)$ and HME $(p<0.0001)$, while Tukey's t-test revealed that STR, LWG and HME all affected body weight development significantly $\left({ }_{P}<0.05\right)$ in experimental cane rats. FRIN strain exhibited highest $\left({ }_{P}<0.05\right)$ live weight of $3.06 \pm 0.05 \mathrm{~kg}$ while Lawole strain recorded mean weight of $2.94 \pm 0.84 \mathrm{~kg}$. Bamidele was in-between the two extremes with a live mean weight of $2.85 \pm 0.68 \mathrm{~kg}$. Weight category of $4.10-5.00 \mathrm{~kg}$ recorded highest mean body weight of $4.34 \pm 0.40 \mathrm{~kg}$ while weight category $(\leq 2.0 \mathrm{~kg})$ gave least mean weight of $1.88 \pm 0.32 \mathrm{~kg}$. HME composed of the immediate environment surrounding grass-cutters directly in each house. House A provided best conditions for growth and resulted mean body weight of $3.55 \pm 0.09 \mathrm{~kg}$ while House $\mathrm{B}$ and $\mathrm{C}$ resulted in body weights of $3.11 \pm 0.70$ and $2.71 \pm 0.97 \mathrm{~kg}$ respectively. Thus within factors, all levels differ significantly $(p<0.05)$ from each other

\begin{tabular}{|c|c|c|c|c|c|c|}
\hline Factor & Level & $\begin{array}{l}\text { No. } \\
\text { of } \\
\text { Indiv. }\end{array}$ & $\begin{array}{l}\text { Initial } \\
\text { Weight }\end{array}$ & $\begin{array}{l}\text { Final } \\
\text { Weight }\end{array}$ & $\begin{array}{l}\text { Weight } \\
\text { Gain }\end{array}$ & $\begin{array}{l}\text { Mean } \\
\text { Weight }\end{array}$ \\
\hline \multirow[t]{3}{*}{ Strain } & FRIN & 34 & 2.99 & 3.09 & 0.10 & $3.06 \pm 0.32^{\mathrm{a}}$ \\
\hline & Bamidele & 28 & 2.68 & 3.08 & 0.40 & $2.85 \pm 0.68^{\mathbf{b}}$ \\
\hline & Lawole & 17 & 3.02 & 3.07 & 0.05 & $2.94 \pm 0.84^{\mathrm{a}}$ \\
\hline Body weight & $\leq 2.0$ & 11 & 1.64 & 2.10 & 0.46 & $1.88 \pm 0.32^{\mathrm{d}}$ \\
\hline \multirow[t]{3}{*}{-group (kg) } & $2.1-3.0$ & 35 & 2.59 & 2.71 & 0.12 & $2.64 \pm 0.41^{\mathrm{c}}$ \\
\hline & $3.1-4.0$ & 22 & 3.51 & 3.57 & 0.06 & $3.53 \pm 0.35^{\mathbf{b}}$ \\
\hline & $4.1-5.0$ & 11 & 4.26 & 4.40 & 0.14 & $4.34 \pm 0.40^{\mathrm{a}}$ \\
\hline \multirow{3}{*}{$\begin{array}{l}\text { House-micro- } \\
\text { environment } \\
\text { (HME) }\end{array}$} & A & 26 & 3.10 & 3.91 & 0.81 & $3.55 \pm 0.90^{\mathrm{a}}$ \\
\hline & B & 26 & 2.91 & 3.15 & 0.24 & $3.11 \pm 0.70^{\mathbf{b}}$ \\
\hline & $\mathrm{C}$ & 27 & 2.77 & 2.80 & 0.03 & $2.71 \pm 0.97^{\mathrm{c}}$ \\
\hline
\end{tabular}




\section{Jesuyon and Bankole}

Interactive effect of strain $x$ live weight category on body weight development of cane rat

Strain means within LWGs of 2.1-3.0 kg were $2.66 \pm 0.43,2.71 \pm 0.40$ and $2.46 \pm 0.0 .32$; and for $4.1-5.0 \mathrm{~kg}$ LWGs were $4.23 \pm 0.30,4.37 \pm 0.08$ and $4.53 \pm 0.59$. These results were significantly $(p<0.0001)$ different for FRIN, Bamidele and Lawole respectively. Figure 1 showed the interactive effects of STRxLWG on body-weight development in the three strains. This revealed that Lawole recorded the least body weight of $1.72 \pm 0.25 \mathrm{~kg}$, Bamidele recorded highest body weight of $1.95 \pm 0.33 \mathrm{~kg}$ at $\leq 2.0 \mathrm{~kg}$ weight category but Lawole showed the highest body weight of $4.53 \pm 0.59 \mathrm{~kg}$ at $4.1-5.0 \mathrm{~kg}$ weight group respectively. FRIN recorded body weight of $1.77 \pm 0.28 \mathrm{~kg}$ in-between the two strains at lowest weight category but recorded the least body weight of $4.23 \pm 0.30 \mathrm{~kg}$ at $4.1-5.0 \mathrm{~kg}$.

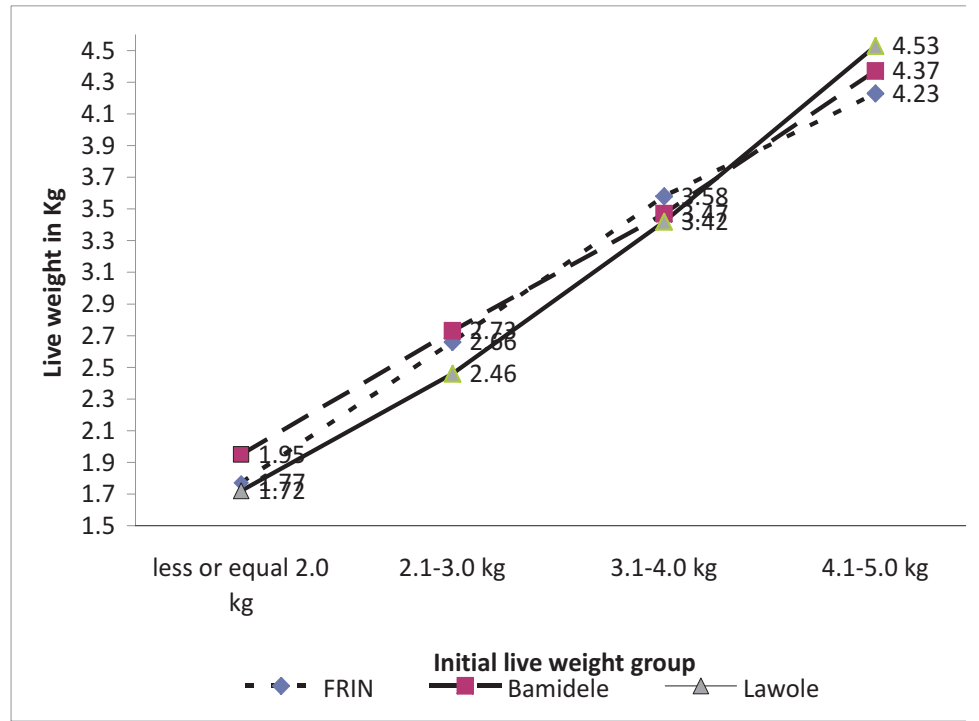

Figure 1: Effect of Strain $x$ Initial live weight-group interaction on b ody weight development of cane rats in the humid tropics

Interactive effect of strain $x$ housemicroenvironment on body weight development of cane rat

The effect of STRxHME interaction on body weight development of experimental animals is shown in Figure 2. Within STR, significant $(p<0.0016)$ differences were observed between HME $\mathrm{A}, \mathrm{B}$ and $\mathrm{C}$ in FRIN (3.59 $\pm 0.59 ， 3.18 \pm 0.71$ and $2.69 \pm 0.66 \mathrm{~kg})$ and in Lawole $(4.09 \pm 0.74$, $3.92 \pm 0.16$ and $2.52 \pm 0.35 \mathrm{~kg})$ strains while there were no significant differences $(p>0.05)$ in the body weight of Bamidele $(3.01 \pm 0.89,2.89 \pm 0.64$ and $2.95 \pm 0.51 \mathrm{~kg})$ between houses. Results further revealed that FRIN and Lawole responded similarly to experimental micro-environments in houses $\mathrm{A}>\mathrm{B}>\mathrm{C}$ with decreasing performance, while Bamidele responded with better performance in house $\mathrm{C}$. Lawole strain recorded the most depression in body weight in house $\mathrm{C}$. Thus there was a change in order of superiority of strains for body weight in house $\mathrm{C}$ (Bamidele $>$ FRIN $>$ Lawole). Other levels of interaction, namely LWGXHouse $(\mathrm{p}<0.0024)$ and StrXLWGXHouse 


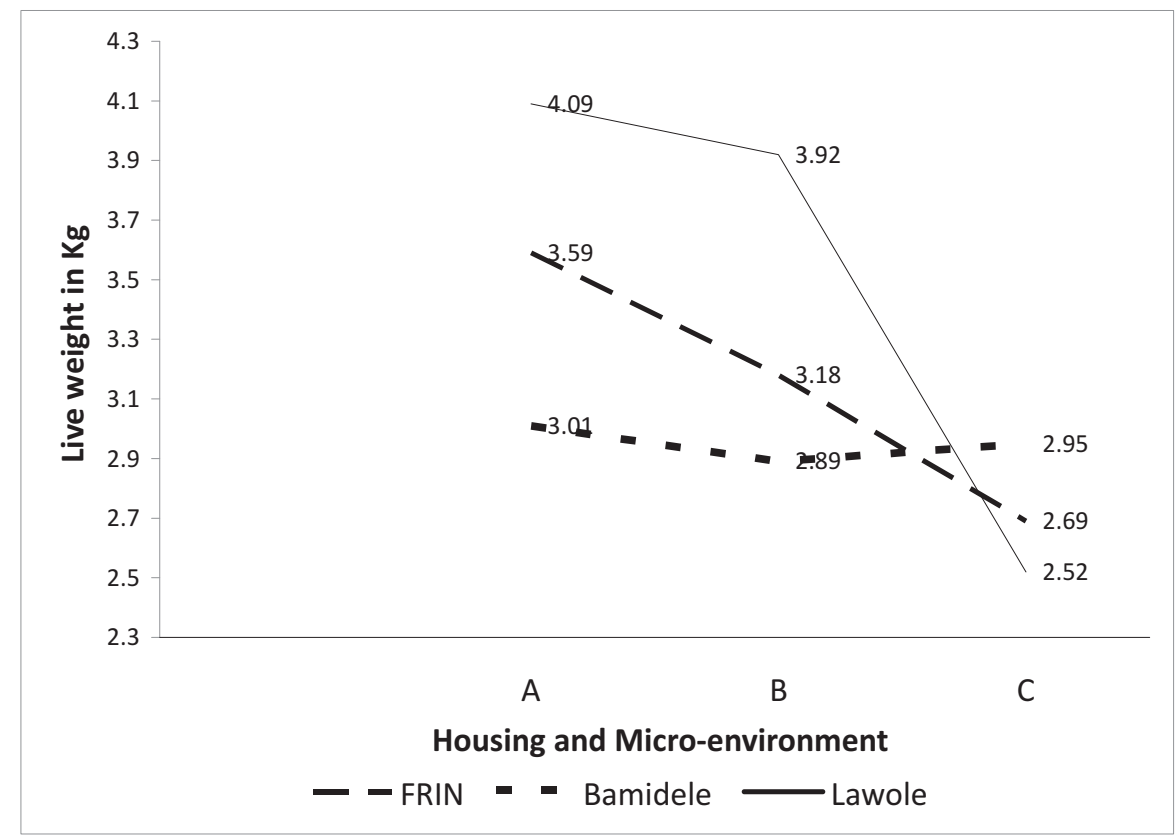

Fig. 2: Strain $x$ House-micro-environment interaction on body weight deve lopment of cane rats in the humid tropics

\section{Discussion}

Under interactive influence of STRxLWG, strains demonstrated consistent development within and between bodyweight categories. Lawole recorded least mean body weight at lowest LWG, but had highest mean body weight at the highest LWG. FRIN had superior body weight $(3.58 \mathrm{~kg})$ at $3.1-4.0 \mathrm{~kg}$ LWG and thus indicated its most critical weight range for development. Bamidele recorded highest body weight at the lowest LWG, but retained live weights in-between FRIN and Lawole at the uppermost weight range. The varying growth responses between strains at 2.1-3.0 and 4.1-5.0kg LWGs were due to strain differences and therefore classified their genetic potentials for weight development at these ranges. Further study revealed that under interaction of STRxLWG the relative growth performance of strains in order of superiority was Lawole $>$ Bamidele $>$ FRIN while the influence of initial body weights only persisted to the $2.1-3.0 \mathrm{~kg}$ weight category but not till higher body weights in all strains respectively. Results implied differences in genetic ability for body weight development between FRIN and Bamidele. Body weight difference between FRIN-Lawole and BamideleLawole strains were low. Bamidele recorded least mean body weight and least body weight variations, while Lawole recorded the highest body weight in HME $\mathrm{A}$; and its body weight development depressed in HMEs B and C. Thus the larger cane rat strains reacted with greater body weight variations in the presence of STRXHME interaction. Webster and Wilson (1980) reported that at temperatures above $29.4^{\circ} \mathrm{C}$, appreciable depression in growth rate occurred with uniform retardation of all body measurements except belly girth. This result suggested raising Lawole and FRIN 


\section{Jesuyon and Bankole}

strains within their thermo-neutral zones in order to express optimum genetic ability for growth and development. Therefore, a cooler and milder micro-environment could elicit superior genetic attributes for growth in both strains in the environment.

Since Bamidele demonstrated least body weight variations and sensitivity between HMEs, it appeared to be the best adjusted strain to HMEs used. The differences observed between strains may be connected with their genotypic abilities, differing amounts of hormonal secretions, possible depression of growth hormone secretions (Foxcroft, 1980) and decreased growth hormone secretion due to various stress (Bennington, 2017) factors from the environmental under varying conditions of STRxHME. Falconer and Mackay (1996) opined that interaction between genotype and environment is a source of variation of phenotypic values, and which in most cases, are inseparable from the environmental variance. Since STRxHME measured adaptability of strains to housing environment, this result confirms previous findings that smaller genotypes are more adaptable to inclement environmental conditions (Horst, 1981). Bamidele strain was therefore recommended for rearing since it elicited superior ability to withstand adverse conditions with least body weight variations. The significant effect of STRXLWGXHME interaction also revealed the nature of the complex interactions taking place between strain, body weight and house as it affects body weight development of cane rats in the environment.

\section{Conclusions and Applications}

The study revealed that strain, housemicro-environment and live weight contributed to body weight development in cane rats, which could be rapid at certain lower and upper body weight ranges. Interactive effect of STRxHME had greatest negative effect on body weight development in the study. Good microenvironment would promote cane rat husbandry and breeding in the tropics since the nature of these interactions are very complex to unravel physiologically.

Conflict of Interest Statement: Authors declare no conflict of interest.

\section{References}

Annor, S. Y., Ahunu, B. K., Aboagye, G. S., Boa-Amponsem K. and Cassady. J. P. 2012. Non-genetic factors affecting grasscutter production traits. 1. Growth traits. World Applied Sciences Journal 18 (10): 1412-1424.

Annor, S. Y., Kagya-Agyemang, J. K., Abbam, J. E. Y., Oppong, S. K. and Agoe, I. M. 2008. Growth performance of grasscutter (Thryonomys swinderianus) eating leaf and stem fractions of Guinea grass (Panicum maximum). Volume 20 (8): Article $\begin{array}{llll}\# & 1 & 2 & 5\end{array}$. http://www.1rrd.org/lrrd20/8/anno 20125.htm

Asibey, E. O. A. and Addo, P. G. 2000. The grasscutter, a promising animal for meat production. In: Turnham D. (ed.). African perspective practices and policies supporting sustainable development. Scandinavian College Seminar, Denmark. Weaver Press, Harare, Zimbabwe. Pages 23-45.

Bennington, V. 2017. Growth Hormone: How Does It Work and Why Do Wom en H a ve More? https://breakingmuscle.com/learn 
Effects of strain, live weight and micro-environment on body weight development of cane rat

Igrowth-hormone-how-does-itwork.

Falconer, D. S. and Mackay, T. F. C. 1996. Introduction to quantitative genetics. Adaptation. genotypeenvironment interaction. 132-133. 321-325. 4th Ed. Longman. New York.

Foxcroft, G. R. 1980. Growth and breeding performance in animals and Birds. In: Growth in animals by T. L. J. Lawrence. Ed. Pages 245. Butterworths. London.

Ghana environmental protection and control (GEPC). 1995. In: Addo, P. Detection of mating, pregnancy and imminent parturition in the grasscutter (Thryonomys swinderianus). Livestock Research for Rural Development 14 (4) 2002.

Hemmer, H. 1990. Domestication, the decline of environment appreciation. Cambridge University Press, Cambridge. page 24

http://onlinelibrary.wiley.com/doi $110.1046 / \mathrm{j} .1420$ 9101.1992.5020356.x/epdf.

Horst, P. 1981. Constraints on the genetic improvement of non-ruminants in the tropics. Animal Research and Development. 14:120-135.

Jori, F. and Chadonnet, P. 2001. Cane rat farming in Gabon. Status and Perspectives. Presentado en 5th International Wildlife Ranching Symposium, Pretoria, Sudafrica en M a r z o. $20001.33-80$. http://www.tdx.cat/bitstream/hand $\underline{\text { le }}$

Meat Science (2015). Growth and development of meat animals.http://meat.tamu.edu/ ansc-307-honors/growth/
Ngoula, F., Ajiahoung-Kemassong, F., Defang-Fualefac, H., Kenfack, A., Téguia, A. and Tchoumboué, J. 2012. Effects of feed supplementation period on some reproductive parameters of female cane rats (Thryonomys swinderianus). International Journal of Livestock Production. 3 (7): 78-82.

Ntiamoa-Baidu. 1980. The ixodid parasites of the greater cane rats. https://www.era.lib.ed.ac. uk/handle/1842/7453.

Okorafor, K. A., Okete, J. A., Eleng, I. E. and Odaibo, A. B. 2013. Seasonal variations in the mean body weight, length and capture rate of cane rats (Thryonomys swinderianus) in Ibaban, Oyo State, Nigeria. European Journal of Experimental Biology. 3(3):301-306.

Olukole, S. G. and Obayemi, T. E. 2010. Histo-morphometry of the testes and epididymis in the domesticated adult African great cane rat (Thryonomys swinderianus). Int. J. Morphology $28(4): 1251-1254$.

Olukole, S. G.; Oyeyemi, M. O. and Oke, B. O. 2014. Semen characteristics and spermiogram of the African greater cane rat (Thryonomys swinderianus, Temminick). Slovak J. Anim. Sci., 47 (3): 125131.

Opara, M. N. 2012. Zoonotic Role of the $\begin{array}{llllllllllll}\mathbf{G} & \mathbf{r} & \mathbf{a} & \mathbf{s} & \mathbf{s} & \mathbf{c} & \mathbf{u} & \mathbf{t} & \mathbf{t} & \mathbf{e} & \mathbf{r} & \text {. }\end{array}$ http://www.intechopen.com/dow nload/pdf/34764. p. 53-62.

Owen, O. J. and Dike, U. A. 2012. Grasscutter (Thryonomys swinderianus) husbandry in 
Nigeria: a review of the potentialities, opportunities and challenges. Journal of Environmental Issues and Agriculture in Developing Countries. 4(1): 104

Peters, S. O., Ikeobi, C. O. N., Ozoje, M. O. and Adebambo, O. A. 2005. Modelling growth in seven chicken genotypes. Nig. J. Anim. Prod. 32 (1): 28-38.

SAS/STAT Version 8. 1999. The SAS System for Windows, Nashville Enabled. SAS Institute Incorporated, N.C, USA

Smith, M., Staples, L., Dyer, B. and Hunt, W. 2002. Incorporation of a z i n p hos phide rodenticide into integrated management of rats in sugarcane crops. Proc. Aust. Soc. Sugar Cane Technol. 24.
Yapi, Y. M., Gidenne, T., Yarizon, Y., Segura, M., Zongo, D. and Enjalbert, F. 2012. Post weaning changes in the digestive physiology and caecal fermentative activity in the greater c ane rat (Thryonomys swinderianus). African Zoology. $47(2): 311-320$.

Yeboah, S. and Adamu, E. K. 1995. The cane rat. Biologist, 42 (2):86-87.

Webster, C. C. and Wilson, P. N. 1980. Adaptation of livestock to tropical environments. 2nd Edition. ELBS/ Longman. pages 441 .

Wogar, G. S. I. and Agwunobi, L. N. 2012. Performance and Energy Requirements of Gestating Grasscutters Fed Agro-Industrial By-Products. Journal of Agricultural Science. 4 (3): 275280.

Received: $27^{\text {th }}$ August, 2016 Accepted: $4^{\text {th }}$ March, 2017 